\title{
Effects of whey powder on fermentation quality, nutritive value, and digestibility of alfalfa silage
}

\author{
S. Özüretmen ${ }^{1, *}$, H. Özelçam ${ }^{1}$ and H.H. İpçak ${ }^{2}$ \\ ${ }^{1}$ Ege University, Faculty of Agriculture, Department of Animal Science, İmir, 35100, Turkey \\ ${ }^{2}$ Dicle University, Faculty of Agriculture, Department of Animal Science, Diyarbakır, 21280, Turkey
}

KEY WORDS: alfalfa, digestibility, net energy, silage, whey powder

Received: 21 September 2021

Revised: 15 December 2021

Accepted: 1 February 2022

${ }^{*}$ Corresponding author:

e-mail: sema.ozuretmen@cpturkiye.com

\begin{abstract}
The aim of the study was to investigate the effects of whey powder (WP) on the fermentation quality, nutritive value, and digestibility of ensiled alfalfa (Medicago sativa L.). Alfalfa treated with different doses of WP $(0,2$, and $4 \%$ fresh matter silage) was ensiled in plastic drums for 60 days. The results of the study revealed that the physicochemical composition and fermentation quality of the alfalfa silage improved and that mold growth was inhibited in the groups treated with 2 and 4\% WP in comparison to that in the control. Production of $\mathrm{CO}_{2}$ (day 7 ) was much lower in silages treated with 2 and $4 \%$ WP (3.77 and $1.85 \mathrm{~g} / \mathrm{kg}$ dry matter (DM), respectively) than in the control group $(21.36 \mathrm{~g} / \mathrm{kg} \mathrm{DM})$. In addition, in vivo dry matter digestibility (DMD) was much higher in the group treated with 4\% WP (76.45\%) than in the control one $(55.82 \%)$. In this treatment group, all apparent digestibility of coefficients in vivo from crude nutrient contents and cell wall fractions significantly increased and hence raised the net lactation energy value from 1.18 to $1.31 \mathrm{Mcal} / \mathrm{kg}$ DM. However, although the in vitro DMD was higher in the silages treated with WP than in the control one and the dose was significant, there was no strong correlation between in vivo and in vitro values. According to our results, WP could provide an advantage for the conservation of alfalfa silage. In addition, WP could be evaluated as a sustainable silage additive.
\end{abstract}

\section{Introduction}

Alfalfa (Medicago sativa L.) is a perennial legume with a high yield which is also rich in vitamins and minerals. It can be used as animal feed in the form of green herbage, hay, or silage. Because grazing on fresh alfalfa can cause tympani, it is very limited (Jonker and Yu, 2016). Although the dried form is generally preferred as animal feed, the leaves are easily broken and lost during this process when drying to the appropriate storage moisture of $12 \%$, also the botanical fraction balance (leaf:stem ratio) shifts toward the cellulosic structure. This decreases protein content, digestibility, and quality of the forage, reduces the alfalfa nutritional value, and increases the cost of feed. On the other hand, it could be possible to obtain successful silage by using additives that stimulate fermentation, such as water-soluble carbohydrates (Keener, 2019).

Whey is a byproduct resulting from the processes of converting milk into cheese. It has high water content $(>90 \%)$ and its major constituent is lactose (77\% of the total solids). Whey powder (WP) is the dried form of it. It contains high content of lactose $(69-76 \%)$, low content of water $(<7 \%)$ and is rich in protein $(\beta$-lactoglobulin and $\alpha$-lactalbumin), vitamins $\left(\mathrm{B}_{2}, \mathrm{~B}_{5}\right.$ and $\left.\mathrm{C}\right)$ and minerals (EWPA, 2016). Each year, more than $200 \mathrm{mln}$ t of whey is generated globally, and this value is increasing by $2 \%$ each year (Mariotti et al., 2020). 
However, a large part of whey is processed to dried form to be used in the food and feed industry (Królczyk et al., 2016; El-Tanboly et al, 2017). In February 2022 the price of WP used as animal feed ranged between 1.154-1.340 €/t in Europe and USA (Anonymous, 2022). So that, WP could be more affordable than other silage additives like inoculants or organic acids, if its use becomes more widespread. It is well known that WP used economically in milk replaces is healthy for young animals. This by-product has been evaluated for increasing calf growth and can be used as both a major protein and an energy source for replacing milk (Huuskonen, 2017). It can be also used in concentrate feed replacing starch due to high lactose content (El-Shewy, 2016). Some studies have revealed that whey has the potential as a silage additive (Castaño and Villa, 2017; Keener, 2019). But the studies on dried form of whey as silage additive are limited. However, WP can also have a stimulating effect on alfalfa with low water-soluble carbohydrates during fermentation because of its high lactose content and can be more economical than molasses. So, the aim of the present study was to investigate the effects of WP at different doses $(0,2$, and $4 \%$ ) on the fermentation quality, nutritive value, and digestibility of ensiled alfalfa.

\section{Material and methods}

\section{Alfalafa and whey powder}

Alfalfa was harvested in the early bloom of the fifth cutting and was chopped to $\sim 1.5-2.0 \mathrm{~cm}$ and allowed to wilt until the dry matter (DM) content was $\sim 29 \%$ before ensiling (Table 1). Whey protein was purchased from Maybi (Malkara-Tekirdağ,Turkey) and was obtained from sweet, fresh, pasteurized whey. The whey had been spray-dried without using any preservatives or additives and demineralized. Whey powder containing less protein and more lactose was preferred in the present study to be better carbohydrate source for alfalfa silage fermentation.

\section{Silage preparation}

Alfalfa treated with different doses $(0,2,4 \%$ fresh matter silage) of WP was ensiled in 120-1 plastic drums. All groups were ensiled again in $2 \mathrm{~kg}$ jars for aerobic stability. The ensiling was determined according to silage-making techniques (Kılıç, 1986). Three replicates were used for each group in a completely randomised design and 60 days of storage. Four analyses from each replicate drum was performed to identify chemical and microbiological properties, and in vitro DM digestibility.
Table 1. Chemical composition of alfalfa before ensiling, \% dry matter (DM)

\begin{tabular}{cclc}
\hline \multicolumn{4}{l}{ Alfalfa chemical composition } \\
\hline $\mathrm{DM}^{*}$ & 28.94 & $\mathrm{NFC}$ & 17.55 \\
$\mathrm{OM}$ & 84.62 & $\mathrm{NDF}$ & 46.92 \\
$\mathrm{CA}$ & 15.38 & $\mathrm{ADF}$ & 37.91 \\
$\mathrm{AIA}$ & 4.64 & $\mathrm{ADL}$ & 7.26 \\
$\mathrm{CP}$ & 17.45 & $\mathrm{HEM}$ & 9.02 \\
$\mathrm{EE}$ & 2.70 & $\mathrm{CEL}$ & 30.65 \\
$\mathrm{CF}$ & 29.65 & $\mathrm{WSC}$ & 4.70 \\
$\mathrm{NfE}$ & 34.83 & $\mathrm{BC}$ & $73.78^{*}$ \\
\hline Whey powder chemical composition & \\
\hline DM & 95.0 & $\mathrm{EE}$ & 0.24 \\
$\mathrm{CA}$ & 6.50 & $\mathrm{CP}$ & 14.20 \\
Lactose & 75.60 & $\mathrm{pH}$ & 6.83 \\
\hline
\end{tabular}

* value of fresh matter silage; $\mathrm{OM}$ - organic matter, $\mathrm{CA}$ - crude ash, AIA - acid insoluble ash, CP - crude protein, EE - ether extract, $\mathrm{CF}$ - crude fibre, NfE - nitrogen-free extract, NFC - nonfibrous carbohydrate, NDF - neutral detergent fibre, ADF - acid detergent fibre, ADL - acid detergent lignin, HEM - hemicellulose, CEL cellulose, WSC - water-soluble carbohydrate, BC - buffer capacity

\section{Chemical analyses}

Samples were dried at $65^{\circ} \mathrm{C}$ for $48 \mathrm{~h}$ and were ground in a grinder with $1 \mathrm{~mm}$ sieve. All samples were analyzed using the following methods: crude nutrients (DM, crude protein (CP), ether extract (EE), and crude fibre (CF)) using the Weende analysis (Menke and Huss, 1975), cell-wall components (neutral detergent fibre (NDF), acid detergent fibre (ADF), acid detergent lignin (ADL)) using the fibre bag system as modified by Goering and Van Soest (1970), organic acids (acetic acid (AA), butyric acid (BA), lactic acid (LA)) using the distillation method adapted from Lepper (Naumann and Bassler, 1993), water-soluble carbohydrates using a spectrophotometer and an anthrone-thiourea method (Anonymus, 1986), ammonia nitrogen $\left(\mathrm{NH}_{3}-\mathrm{N}\right)$ rates using the microdistillation method (Anonymus, 1986), and aerobic stability using the method of Ashbell et al. (1991). The nitrogen-free extract (NfE) was calculated as $\% \mathrm{NfE}=100 \%-(\mathrm{CP} \%+\mathrm{CF} \%+\mathrm{ash} \%$ + fat $\%)$ and the nonfibrous carbohydrate (NFC) was calculated as NFC $=100-(\mathrm{NDF} \%+\mathrm{CP} \%+$ fat $\%+a s h \%$ ) (all nutrients are in dry matter) (NRC, 2001). Hemicellulose (HEM) content was calculated from NDF - ADF, and cellulose (CEL) content from ADF - ADL. Before ensiling, the fresh material buffer capacity was detected using the method of Playne and McDonald (1966).

All $\mathrm{pH}$ values of the samples were measured using a desktop pH meter (Hanna HI2211-02; Chennai, Tamil Nadu, India). The physical characteristics of all silages were determined using three different parameters of colour, odour, and structure. 
The Flieg score:

Flieg score $=220+(2 \times \mathrm{DM} \%-15)-40 \times \mathrm{pH}$, was calculated according to silage dry matter (DM) content and pH value (Kılıç, 1986; DLG, 1987).

The relative feed value (RFV) was calculated according to Rohweder et al. (1978) from the equation:

$$
\begin{gathered}
\text { RFV }=\text { dry matter intake }(\mathrm{DMI}) \times \text { digestible dry } \\
\text { matter }(\mathrm{DDM}) / 1.29,
\end{gathered}
$$

where: DMI, $\%$ of body weight $(\mathrm{BW})=120 /$ (neutral detergent fibre (NDF), $\%$ of dry matter (DM)); and DDM, $\%$ of $\mathrm{DM}=88.9-0.779 \times($ acid detergent fibre (ADF), $\%$ of DM).

\section{Microbial analyses}

The colonies of mold-yeast were counted using Tournas et al. (1998) and counts were expressed as colony-forming units per $\mathrm{g}(\mathrm{CFU} / \mathrm{g})$. Malt extract agar was used for the enumeration of mold/yeast and the Petri plates were incubated at $25{ }^{\circ} \mathrm{C}$ for 3-5 days under aerobic conditions.

\section{In vitro digestibility}

In vitro DM digestibility (IVDMD) of the silages was determined using the enzyme technique, which is based on incubating forages with pepsin (2000 FIP-U/g) and cellulase enzyme (Onozuka R 10 from Trichoderma viride; Merck, Darmstadt, Germany). The incubation time and temperature of each enzyme were $24 \mathrm{~h}$ at $38{ }^{\circ} \mathrm{C}$, respectively. After incubation, the forages were washed, dried at $105^{\circ} \mathrm{C}$ for $24 \mathrm{~h}$, and incinerated in a muffle furnace at $550{ }^{\circ} \mathrm{C}$ for $4 \mathrm{~h}$ (De Boever et al., 1986).

\section{In vivo digestibility}

All procedures concerning animal usage were approved by the Ethics Committee of Ege University, Izmir, Turkey (No: 2016-001).

Nine Kivircik rams, $1-1.5$ years old with similar physical characteristics and $45.0 \pm 3.0 \mathrm{~kg}$ body weight were used in the study. They were fed twice/ day at 8:30 and 16:30 and had ad libitum access to drinking water and lick blocks during the trial. The study was conducted using a completely randomised design ( 3 rams per each treatment).

To evaluate in vivo digestibility, animals were maintained in individual pens for 12 days ( 7 days of adjustment period +5 days of sampling). Feed intake was calculated as 1.2 fold animal maintenance requirements and feed $(3.5 \mathrm{~kg}$ of fresh matter silage). The manure was collected in the morning before feeding during the sampling period. The manure picked up from each group was weighed and $100-150 \mathrm{~g}$ of it was kept into a jar by adding
3-5 drops of chloroform. There were three jars of the manure from one animal. Each jar with manure was analysed four times. All samples were kept in the refrigerator at $-20{ }^{\circ} \mathrm{C}$ until analysis. The apparent digestibility of coefficient (ADC) of the groups was calculated according to GfE (1991):

ADC $(\%)=($ feed intake - throw out with manure $)$ / feed intake) $\times 100$.

Total digestible nutrients (TDN) were calculated according to NRC (2001) and Küçük (2019):

$\mathrm{TDN}(\%)=((\mathrm{CP}(\%) \times \mathrm{ADC}$ of $\mathrm{CP})+(\mathrm{CF}(\%) \times$ $\mathrm{ADC}$ of $\mathrm{CF})+(\mathrm{NfE}(\%) \times \mathrm{ADC}$ of $\mathrm{NfE})+(\mathrm{EE}(\%)$ $\times \mathrm{ADC}$ of $\mathrm{EE} \times 2.25$ ),

where: $\mathrm{CP}$ - crude protein, $\mathrm{ADC}$ - apparent digestibility of coefficient, $\mathrm{CF}$ - crude fibre, NfE - nitrogen free extract, EE - ether extract.

Net energy for lactation $\left(\mathrm{NE}_{\mathrm{L}}\right)$ was calculated according to NRC (2001):

$\mathrm{NE}_{\mathrm{L}}(\mathrm{Mcal} / \mathrm{kg})=0.0245 \times \mathrm{TDN}(\%)-0.12$, where: TDN - total digestible nutrients.

\section{Statistical analyses}

All data were conducted to one-way analysis of ANOVA by employing the procedure SPSS version 22.0 (IBM Corp., Armonk, NY, USA) package software (SPSS, 2013). A completely randomised design was used according to the following model:

$$
\mathrm{yij}=\mu+\alpha \mathrm{i}+\varepsilon \mathrm{ij},
$$

where: yij - dependent variable, $\mu$ - overall mean, $\alpha \mathrm{i}$ - fixed effect of treatment ( $\mathrm{i}=1$ to 3 ), $\varepsilon \mathrm{ij}$ - random error.

Duncan multiple comparison test was used to compare the differences among the mean values $(P<0.05)$.

\section{Results}

\section{Chemical composition}

In comparison with the control group (Table 2), the addition of WP to alfalfa silage led to an increase in the content of DM of $4.42 \%$ in the samples with $4 \% \mathrm{WP}$ and of $1.63 \%$ in the samples with $2 \% \mathrm{WP}$ $(P<0.05)$. No effect of WP addition on OM, CP, and EE $(P>0.05)$ was observed.

The addition of WP also increased the NfE content in the silage in comparison to control samples $(P<0.05)$, but there was no dose-depending effect $(P>0.05)$. On the other hand, NFC values in silages ranged from 17.06 to $21.92 \%$, and the difference between the groups was important $(P<0.05)$. The addition of WP also affected RFV values in the silages. According to the data, in the groups treated 
Table 2. Effect of whey protein (WP) on crude nutrients, nonfibrous carbohydrate (NFC) and relative feed values (RFV), and cell-wall fractions in alfalfa silage, \% dry matter (DM)

\begin{tabular}{lcccr}
\hline \multirow{2}{*}{ Indices } & \multicolumn{2}{l}{ WP treatement, $\%$} & \multirow{2}{*}{ P-value } \\
\cline { 2 - 5 } & $0(n=3)$ & $2(n=3)$ & $4(n=3)$ & \\
\hline DM & $29.85 \pm 0.18^{\mathrm{c}}$ & $31.48 \pm 0.18^{\mathrm{b}}$ & $34.27 \pm 0.13^{\mathrm{a}}$ & $<0.001$ \\
$\mathrm{OM}$ & $81.34 \pm 0.22$ & $81.98 \pm 0.20$ & $81.25 \pm 0.31$ & 0.090 \\
$\mathrm{CP}$ & $19.16 \pm 0.32$ & $18.88 \pm 0.16$ & $18.72 \pm 0.12$ & 0.320 \\
$\mathrm{EE}$ & $3.48 \pm 0.08$ & $3.22 \pm 0.13$ & $3.25 \pm 0.10$ & 0.182 \\
$\mathrm{CF}$ & $25.89 \pm 0.45^{\mathrm{c}}$ & $24.19 \pm 0.01^{\mathrm{b}}$ & $22.62 \pm 0.43^{\mathrm{a}}$ & 0.002 \\
NfE & $32.79 \pm 0.39^{\mathrm{b}}$ & $35.67 \pm 0.30^{\mathrm{a}}$ & $36.87 \pm 0.57^{\mathrm{a}}$ & $<0.001$ \\
NFC & $17.06 \pm 0.46^{\mathrm{c}}$ & $19.22 \pm 0.29^{\mathrm{b}}$ & $21.92 \pm 0.26^{\mathrm{a}}$ & $<0.001$ \\
RFV & $144.64 \pm 4.36^{\mathrm{b}}$ & $148.35 \pm 1.73^{\mathrm{b}}$ & $167.12 \pm 5.09^{\mathrm{a}}$ & 0.005 \\
NDF & $41.69 \pm 0.35^{\mathrm{b}}$ & $40.88 \pm 0.22^{\mathrm{b}}$ & $37.27 \pm 0.24^{\mathrm{a}}$ & 0.001 \\
ADF & $30.56 \pm 0.72^{\mathrm{b}}$ & $30.73 \pm 0.50^{\mathrm{b}}$ & $28.33 \pm 0.38^{\mathrm{a}}$ & 0.004 \\
ADL & $7.30 \pm 0.16$ & $6.99 \pm 0.26$ & $6.78 \pm 0.14$ & 0.124 \\
HEM & $10.41 \pm 0.54$ & $9.37 \pm 0.53$ & $8.96 \pm 0.35$ & 0.109 \\
CEL & $23.88 \pm 1.27$ & $23.07 \pm 0.36$ & $21.61 \pm 0.41$ & 0.153 \\
\hline OM & & & &
\end{tabular}

$\mathrm{OM}$ - organic matter, CP - crude protein, EE - ether extract, $\mathrm{CF}$ - crude fibre, NfE - nitrogen-free extract, NDF - neutral detergent fibre, ADF - acid detergent fibre, $A D L$ - acid detergent lignin, HEM - hemicellulose, CEL - cellulose; ${ }^{a-c}$ means within the row with different superscripts are significantly different at $P<0.05$

with WP higher RFV values than in the control one were noted, and this effect increased with the WP addition $(P<0.05)$.

The addition of $4 \%$ WP was more effective on NDF fraction - the lowest NDF value was found in this group $(P<0.05)$. Similarly, only treatment with $4 \%$ WP had a significant effect on the ADF fraction in the silage and lowered its value $(P<0.05)$. However, the both doses of WP had no effect on ADL, HEM, and CEL contents in the silages $(P>0.05)$.

\section{Fermentation quality, aerobic stability and microbiology}

The data presented in Table 3 shows that WP decreased the $\mathrm{pH}$ value and improved the fermentation quality of studied silages. As the dose increased, the silage's acid composition improved, and the $\mathrm{pH}$ of the groups decreased, with the lowest value found in the 4\% WP group. On the other hand, WP also increased the Flieg score by improving the physical properties (structure, smell, and colour). We have also observed that the rams fed silage treated with $4 \%$ WP consumed it readily, which can demonstrate that WP improves the physical quality and enhances the palatability of the silage.

The silages treated with WP had higher LA and AA but lower BA in comparison with the control group $(P<0.05)$; however, no difference was observed among the WP treatment groups $(P>0.05)$. Although this improvement in silage acids increased with the dose, the difference among the treatment groups was not statistically significant. There was no significant effect on $\mathrm{NH}_{3}-\mathrm{N}$ in the silages treated with $2 \% \mathrm{WP}$; however, the $\mathrm{NH}_{3}-\mathrm{N}$ in the silage treated with $4 \%$ WP decreased in comparison to that in the control group.

At day 7 it was observed that the addition of WP reduced the $\mathrm{CO}_{2}$ content in the silages and that the WP dose had a crucial effect $(P<0.05)$. According to the data, the lowest level of $\mathrm{CO}_{2}$ was found in the 4\% WP group, and aerobic deterioration was the highest in the control group. Hence, the highest improvement of aerobic stability was determined in the group with 4\% WP. In addition, it was observed that mold growth was prevented in the groups treated with WP.

\section{In vitro and in vivo digestibilities}

As shown in Table 4, the addition of WP to silages influenced IVDMD $(P<0.05)$. In all groups values between 62.25 and $67.87 \%$ were noted; in the control group IVDMD was the lowest whereas in the $4 \%$ WP group - the highest. However, there was no strong correlation between in vitro and in vivo values for DMD.

Treatment with 4\% WP had a significant effect on the digestibility of all nutrients in alfalfa silage

Table 3. Effect of whey protein (WP) on fermentation characteristics, aerobic stability, and the microbial population in alfalfa silage

\begin{tabular}{lcccl}
\hline \multirow{2}{*}{ Indices } & WP treatment, $\%$ & & \multirow{2}{*}{$P$-value } \\
\cline { 2 - 4 } & $0(\mathrm{n}=3)$ & $2(\mathrm{n}=3)$ & $4(\mathrm{n}=3)$ & $<0.001$ \\
$\mathrm{pH}$ & $5.94 \pm 0.16^{\mathrm{b}}$ & $5.11 \pm 0.21^{\mathrm{a}}$ & $5.09 \pm 0.04^{\mathrm{a}}$ & - \\
Flieg score & 27 (low) & 60 (good) & 70 (good) & $<0.001$ \\
Lactic acid, \% DM & $4.77 \pm 0.29^{\mathrm{b}}$ & $8.03 \pm 0.68^{\mathrm{a}}$ & $8.11 \pm 0.32^{\mathrm{a}}$ & $<0.001$ \\
Acetic acid, \% DM & $2.40 \pm 0.12^{\mathrm{b}}$ & $3.11 \pm 0.16^{\mathrm{a}}$ & $3.47 \pm 0.14^{\mathrm{a}}$ & $<0.001$ \\
Butyric acid, \% DM & $1.98 \pm 0.10^{\mathrm{b}}$ & $0.82 \pm 0.20^{\mathrm{a}}$ & $0.51 \pm 0.08^{\mathrm{a}}$ & $<0.001$ \\
$\mathrm{NH}_{3}-\mathrm{N}, \mathrm{g} / \mathrm{kg} \mathrm{DM}$ & $3.57 \pm 0.14^{\mathrm{b}}$ & $3.57 \pm 0.01^{\mathrm{b}}$ & $2.75 \pm 0.06^{\mathrm{a}}$ & $<0.001$ \\
$\mathrm{CO}_{2}$, g/kg DM (day 7) & $21.36 \pm 1.00^{\mathrm{c}}$ & $3.77 \pm 0.52^{\mathrm{b}}$ & $1.85 \pm 0.22^{\mathrm{a}}$ & - \\
Total mold/yeast, log CFU/g & $1.36 \pm 0.73$ & $\mathrm{~N} / \mathrm{A}$ & $\mathrm{N} / \mathrm{A}$ & - \\
\hline
\end{tabular}

$\mathrm{DM}$ - dry matter, CFU - colony forming unit, N/A - not available; ${ }^{a-c}$ means within the row with different superscripts are significantly different at $P<0.05$ 
Table 4. Effect of whey powder (WP) on in vitro dry matter digestibility (IVDMD), in vivo digestibility, total digestible nutrients (TDN) and net energy lactation $\left(\mathrm{NE}_{\mathrm{L}}\right)$ in alfalfa silage, in dry matter $(\mathrm{DM})$

\begin{tabular}{|c|c|c|c|c|}
\hline \multirow{2}{*}{ Indices } & \multicolumn{3}{|c|}{ WP treatment, \% } & \multirow{2}{*}{$P$-value } \\
\hline & $0(n=3)$ & $2(n=3)$ & $4(n=3)$ & \\
\hline IVDMD, \% & $62.25 \pm 1.10^{c}$ & $64.91 \pm 0.49^{b}$ & $67.87 \pm 0.65^{a}$ & 0.010 \\
\hline \multicolumn{5}{|l|}{ In vivo, $\%$} \\
\hline \multicolumn{5}{|c|}{ Crude nutrients } \\
\hline DM & $55.82 \pm 2.29^{b}$ & $59.83 \pm 2.09^{b}$ & $76.45 \pm 1.51^{\mathrm{a}}$ & $<0.001$ \\
\hline $\mathrm{OM}$ & $62.18 \pm 1.71^{\mathrm{b}}$ & $66.02 \pm 1.66^{b}$ & $77.32 \pm 1.50^{\mathrm{a}}$ & $<0.001$ \\
\hline $\mathrm{CP}$ & $65.70 \pm 1.74^{b}$ & $70.37 \pm 1.44^{b}$ & $77.87 \pm 1.93^{\mathrm{a}}$ & $<0.001$ \\
\hline $\mathrm{EE}$ & $68.53 \pm 2.08^{b}$ & $69.38 \pm 1.64^{b}$ & $81.10 \pm 1.28^{a}$ & $<0.001$ \\
\hline $\mathrm{CF}$ & $63.87 \pm 1.63^{c}$ & $70.37 \pm 1.44^{b}$ & $77.87 \pm 1.93^{\mathrm{a}}$ & $<0.001$ \\
\hline NfE & $58.21 \pm 2.51^{c}$ & $66.28 \pm 1.50^{b}$ & $79.46 \pm 1.21^{a}$ & $<0.001$ \\
\hline \multicolumn{5}{|c|}{ Cell wall fractions } \\
\hline NDF & $68.23 \pm 1.69^{b}$ & $66.00 \pm 1.44^{b}$ & $77.12 \pm 1.65^{\mathrm{a}}$ & $<0.001$ \\
\hline ADF & $59.38 \pm 2.73^{c}$ & $61.86 \pm 1.85^{b}$ & $72.78 \pm 1.72^{\mathrm{a}}$ & $<0.001$ \\
\hline TDN, \% & $53.19 \pm 0.63^{c}$ & $58.37 \pm 0.33^{b}$ & $66.79 \pm 0.93^{a}$ & $<0.001$ \\
\hline $\mathrm{NE}_{1}, \mathrm{Mcal} / \mathrm{kg}$ & $1.18 \pm 0.01^{c}$ & $1.31 \pm 0.02^{b}$ & $1.52 \pm 0.02^{\mathrm{a}}$ & $<0.001$ \\
\hline
\end{tabular}

$\mathrm{OM}$ - organic matter, CP - crude protein, EE - ether extract, CF - crude fibre, NfE - nitrogen-free extract, NDF - neutral detergent fibre, ADF - acid detergent fibre; ${ }^{a-c}$ means within the row with different superscripts are significantly different at $P<0.05$

$(P<0.05)$. The greatest apparent digestibility coefficient (ADC) values were found in the silages with $4 \%$ WP $(P<0.05)$. No effect on ADC digestibility in silage samples with $2 \%$ WP was noted $(P>0.05)$. However, it was observed that WP addition influenced carbohydrate digestibility. In silages treated with WP higher ADC of CF and NfE contents were noted, and this effect increased with the dose $(P<0.05)$. Treatment with WP improved the digestibility of silages, and dose greatly affected ADC of NDF and ADF. The greatest ADC of NDF was in the $4 \%$ WP silage $(P<0.05)$. In addition, both WP doses had a significant effect on ADF digestibility $(P<0.05)$. Accordingly, the lowest ADC of ADF was observed in the control silage, followed by that in the 2 and $4 \%$ treatment groups $(P<0.05)$. The digestibility of crude nutrients was consistent with $\mathrm{ADC}$ and the parameters increased in the group treated with WP $4 \%$.

Values of TDN were higher in silages treated with WP than in control one $(P<0.05)$. In addition, there was a significant difference among groups concerning $\mathrm{NE}_{\mathrm{L}}$ value $(P<0.05)$. Accordingly, in the silage treated with $4 \% \mathrm{WP}$ the highest $\mathrm{NE}_{\mathrm{L}}$ value was observed; whereas, in the control group it was the lowest $(P<0.05)$.

\section{Discussion}

Chemical composition. It was found that DM and NFC contents of the silages increased along with the increasing dose of WP. It could be associ- ated with the high DM content (95\%) in WP, and so the ability of WP to improve silage fermentation. On the other hand, NFC could play a critical role as a fermentation stimulant in the rumen because of the carbohydrate. It was shown that NFC as a carbohydrate source balancing with nitrogen $(\mathrm{N})$ as a protein source improved rumen microorganisms and $\mathrm{N}$ efficiency in the rumen (Ma et al., 2015). In the present study, slight increase of NFC in the groups treated with WP (with high lactose content) had a positive effect on alfalfa silage digestibility in the rumen because it stimulated $\mathrm{N}$ efficiency and improved rumen microorganisms.

Whey powder treatment improved silages by decreasing their NDF and ADF contents. These results are in line with the results of previous studies on the effect of WP on the cellulose content in the silage (Dash et al., 1974; Fallah, 2019). According to chemical analyses data, it could be stated that WP used as a fermentation stimulant had a significant effect on the carbohydrate structure of the ensiling material by increasing the rate of NFC versus decreasing the rates of NDF and ADF.

Fermentation quality, aerobic stability and microbiology. The $\mathrm{pH}$ value is an important indicator reflecting silage fermentation toward dominant microorganisms either desired or not desired. In the present study WP improved the silage fermentation but not as enough to lower the $\mathrm{pH}$ to $<5$. Bijelić et al. (2015) have reported that DM has a direct effect on pH. Also, Kung (2010) stated that legume silages have a $\mathrm{pH}$ value of more than 4.6 to 4.8 due to low DM value of fresh material $(<30 \%)$ that causes 
clostridial fermentation. Clostridia is undesirable bacteria in silages as it causes protein degradation, DM loss, and production of toxins. However, butyric acid is a marker for growing clostridia and it was not identified in the silages treated with WP in this study. The second reason for such low $\mathrm{pH}$ values is the high buffering capacity of legumes which might be a barrier. On the other hand, $\mathrm{pH}$ values of the silages treated with WP were compatible with some previous studies (Şengül and Aydın, 2019; Kang et al., 2021). Nevertheless, the addition of 2 and 4\% WP was enough to improve other fermentation characteristics, such as aerobic stability and the microbial population in the alfalfa silages, without changing the $\mathrm{pH}$.

Lactic acid is the primary acid responsible for the decrease in silage $\mathrm{pH}$, and the ratio of LA should constitute $65-70 \%$ of the total acids in silages that have undergone successful fermentation. Acetic acid is the second most commonly found volatile acid in silages, and BA should not be $>0.5 \%$ in well-preserved silages because it induces ketosis in lactating cows. High ratios of BA in silage also indicate that feed proteins are broken down and the silage begins to spoil (McDonald et al., 2010; Kung et al., 2018). When the profile of the volatile acids in the silage groups was examined, we observed that the silages treated with WP had higher LA and AA but lower BA than the control. Hence, it is possible that WP could be a good source for improving end products of legume silages. It was found that the AA ratio was slightly higher in the WP groups than in the control one. This moderate increment could be beneficial for improving aerobic stability. Even so, raising the LA ratio and reducing the BA ratio supported the fermentation to occure at the desired level and that the Lactobacillus species were dominant in the fermentation environment in the present study. Furthermore, AA showed a protective property for silages after opening and improved aerobic stability by reducing the $\mathrm{CO}_{2}$ ratio (Kung et al., 2018). Danner et al. (2003) have shown that AA plays a critical role in inhibiting the organisms that create spoilage and successfully inhibits these organisms. These findings are confirmed in our study where the mold growth was not observed in silages treated with WP. Hence, the improvement in aerobic stability and prevention of mold growth in the treatment groups was associated with the increase in the AA ratio in these silages. Our results indicated that adding 4\% WP effectively improved the fermentation quality of the silage.

In vitro and in vivo digestibilities. It was observed that in comparison with the in vivo digestibility, the in vitro results for DMD were higher.
Barchiesi-Ferrari et al. (2011) have shown that cellulase concentration, incubation time, and washing type have a significant effect on enzymatic DMD. During incubation, enzymatic activity or enzyme type might have affected and altered the results of the study. Similarly, it has been reported that as the incubation time increases when using the enzymatic method, while other methods, such as in situ, may decrease it (Olowu and Yaman Fırıncıoğlu, 2019). Additionally, this inconsistency between in vitro and in vivo results could be related to the unpredicted effects of feed additives such as WP on rumen health. Promoting to grow rumen microbiota in a living organism might be an unpredicted effect of $4 \%$ WP addition.

Previous studies have generally shown that WP addition to silage improves the fermentation process (Castaño and Villa, 2017; Fallah, 2019). In some studies, it was also observed that addition of WP significantly increases the digestibility of the alfalfa silage, which is believed to be a result of its high lactose content (Dash et al., 1974; Keener, 2019). Because WP has a stimulating effect as a carbohydrate on fermentation during ensiling, it is presumed that the silages treated with it are of high quality. In the present study, we observed that the WP groups had higher in vivo digestibility resulting from the successful fermentation process. Hence, the increase in DMD in the treated silages was associated with the increased DM content resulting from the addition of WP. This increment in DM rate supported in vitro and in vivo DMD in the group treated with $4 \%$ WP. On the other hand, silage treated with 4\% WP had the $\mathrm{NE}_{\mathrm{L}}$ value closest to that of alfalfa hay (NRC, 2001).

\section{Conclusions}

Chemical composition and fermentation quality of alfalfa silage was improved by the treatment with whey powder (WP). The additive provided a crucial improvement in aerobic stability, and prevent the mold growth. Also, 4\% WP addition significantly increased in vivo nutrient digestibility. Whereas the addition of both 2 and 4\% WP affected the digestibility of crude fibre and acid detergent fibre. Accordingly, it is recommend that silage additives such as WP could be successfully used with legumes as alfalfa, that are difficult to ensilage, and in order to avoid losses in silage digestibility. Also, using whey in ruminant nutrition could prevent environmental pollution caused by industrial wastes and support investments for ecological recycling facilities in cheese factories pulverizing whey to powder. 


\section{Acknowledgements}

This study was supported by TÜBİTAK 1002 - Short Term R\&D Funding Programme (No: 116 O 110) and was included part of Sema ÖZÜRETMEN's PhD thesis. Those who participated were as follows: SÖ: original draft, conceptualization, investigation, data collection, formal analysis, and writing; HÖ: original draft, conceptualization, project administration, supervision, validation, and editing; HHI: in vitro digestibility and the correlation between in vitro and in vivo parameters and contributed to writing this article. The authors also thank TÜBITTAK for financial support.

\section{Conflict of interest}

The authors declare that there is no conflict of interst.

\section{References}

Anonymus, 1986. The Analysis of Agricultural Materials: A Mannual of The Analytical Methods Used by The Agricultural Development and Advisory Service. $3^{\text {rd }}$ Edition. H.M. Stationery Office London

Anonymus, 2022. Whey powder for animal feed prices, https://www. clal.it/en/?section=confronto_whey

Ashbell G., Weinberg Z.G., Azrieli A., Hen Y., Horev B., 1991. A simple system to study the aerobic deterioration of silages. Can. Agric. Eng. 33, 391-393

Barchiesi-Ferrari C., Alomar D., Miranda H., 2011. Pepsin-cellulase digestibility of pasture silages: effects of pasture type, maturity stage, and variations in the enzymatic method. Chil. J. Agric. Res. 71, 249-257

Bijelić Z., Tomić Z., Ružić-Muslić D. et al., 2015. Silage fermentation characteristics of grass-legume mixtures harvested at two different maturity stages. Biotechnol. Anim. 31, 303-311, https://doi.org/10.2298/BAH1502303B

Castaño G.A., Villa L.M., 2017. Use of whey and molasses as additive for producing silage of Cuba OM-22 (Cenchrus purpureus $\mathrm{x}$ Cenchrus glaucum). Cuban J. Agr. Sci. 51, 61-70

Danner H., Holzer M., Mayrhuber E., Braun R., 2003. Acetic acid increases stability of silage under aerobic conditions. Appl. Environ. Microbiol. 69, 562-567, https://doi.org/10.1128/ AEM.69.1.562-567.2003

Dash S.K., Voelker H.H., Muller L.D., Schingoethe D.J., 1974. Dried whey as an additive for reconstituted alfalfa hay silage. J. Dairy Sci. 57, 314-318, https://doi.org/10.3168/jds.S00220302(74)84883-6

De Boever J.L., Cottyn B.C., Buysse F.X., Wainman F.W., Vanacker J.M., 1986. The use of an enzymatic technique to predict digestibility, metabolizable energy of compound feedstuffs for ruminants. Anim. Feed Sci. Technol. 14, 203-214, https://doi. org/10.1016/0377-8401(86)90093-3

DLG - Deutsche Landwirtschafts-Gesellschaft, 1987. Bewertung Von Grünfutter Silage Und Heu. Merkblatt No: 224 (in Deutsch)

El-Shewy A.A., 2016. Whey as a feed ingredient for lactating cattle. Sci. Int. 4, 80-85, https://doi.org/10.17311/sciintl.2016.80.85
El-Tanboly E.S., El-Hofi M., Khorshid, 2017. Recovery of cheese whey, a by-product from the dairy industry for use as an animal feed. J. Nutr. Health Food Eng. 6 (5), 148-154, https://doi. org/10.15406/ jnhfe.2017.06.00215

EWPA - European Whey Processors Association, 2016. Whey in Animal Nutrition - A Valuable Ingredient. Brussels: European Whey Products Association, p. 20

Fallah R., 2019. Effects of adding whey and molasses on corn silage quality, growth performance and health of Simmental fattening calves. Livest. Sci. 10, 91-96, https://doi.org/10.33259/ JLivestSci.2019.91-96

GfE - Gesellschaft fur Ernahrungsphysiologie, 1991. Leitlinien für die bestimmung der verdaulichkeit von rohnahrstoffen an wiederkauern. J. Anim. Physiol. Anim. Nutr. 65, 229-234

Goering H.K., Van Soest P.J., 1970. Forage Fiber Analyses. Agriculture Handbook. No: 379. Washington DC (USA). pp. 829-835

Huuskonen A., 2017. Effects of skim milk and whey-based milk replacers on feed intake and growth of dairy calves. J. Appl. Anim. Res. 45, 480-484, https://doi.org/10.1080/09712119.2 016.1217868

Jonker A., Yu P., 2016. The role of proanthocyanidins complex in structure and nutrition interaction in alfalfa forage. Int. J. Mol. Sci. 17, 793, https://doi.org/10.3390/ijms17050793

Kang J., Tang S., Zhong R., Tan Z., Wu D., 2021. Alfalfa silage treated with sucrose has an Improved feed quality and more beneficial bacterial communities. Front. Microbiol. 12, 670165, https:// doi.org/10.3389/fmicb.2021.670165

Keener L., 2019. Whey powder and food safety risks: a lesson in validation and verification. Food Safety Magazine 16 April 2019, https://www.food-safety.com/articles/6184-whey-powderand-food-safety-risks-a-lesson-in-validation-and-verification. Accessed on: Feb. 10, 2019

Kılıç A., 1986. Silo Yemleri. İzmir-Turkey: Bilgehan Publishers. p. 327 (in Turkish)

Królczyk J.B., Dawidziuk T., Janiszewska-Turak E., Sołowiej B., 2016. Use of whey and whey preparations in the Food Industrya Review. Pol. J. Food Nutr. Sci. 66, 157-165, https://doi. org/10.1515/pjfns-2015-0052

Kung L.J.R., 2010. Understanding the biology of silage preservation to maximize quality and protect the environment. Proceedings, 2010 California Alfalfa \& Forage Symposium and Corn/Cereal Silage Conference, Visalia, CA, 1-2 December, 2010

Kung L.J.R., Shaver R.D., Grant R.J., Schmidt R.J., 2018. Silage review: Interpretation of chemical, microbial, and organoleptic components of silages. J. Dairy Sci. 101, 4020-4033, https:// doi.org/10.3168/jds.2017-13909

Küçük O., 2019. Practical Nutrition of Calf, Heifer, Dairy Cow and Beef Cattle- $2^{\text {nd }}$ Edition. 123p. Kayseri (Turkey)

Ma T., Tu Y., Zhang N.F., Deng K.D., Dia Q.Y., 2015. Effect of the ratio of non-fibrous carbohydrates to neutral detergent fiber and protein structure on intake, digestibility, rumen fermentation, and nitrogen metabolism in lambs. Asian-Australas J. Anim. Sci. 28, 1419-1426, https://doi.org/10.5713/ajas.15.0025

Mariotti M., Fratini F., Cerri D. et al., 2020. Use of fresh Scotta Whey as an additive for alfalfa silage. Agronomy 10,365 , https://doi. org/10.3390/agronomy10030365

McDonald P., Edwards R.A., Greenhalgh J.F.D., Morgan C.A., 2010. Animal Nutrition. $7^{\text {th }}$ Edition. Edinburgh, UK. p. 71. ISBN: 0582419069

Menke K.H., Huss W., 1975. Tierernährung und Futtermittelkunde Verlag Eugen Ulmer, Stuttgart (Germany). pp. 74-79, (in Deutsch). ISBN: 3-8001-2410-6 
Naumann C., Bassler R., 1993. Die Chemische Unterschungen Von Futtermitteln. Methodenbuch Band III, VDLUFA-Verlag, Frankfurt (Germany) (in Deutsch)

NRC - National Research Council, 2001. Nutrient Requirements of Domestic Animals. $7^{\text {th }}$ Rev. Edit. National Research Council, Washington, DC (USA)

Olowu O.O., Yaman Fırıncıoğlu S., 2019. Feed evaluation methods: performance, economy and environment. EJAR. 3, 48-57

Playne M.J., McDonald P., 1966. The buffering constituent of herbage and silage. J. Sci. Food Agric. 17, 264-268

Rohweder D.A., Barnes R.F., Jorgensen N.,1978. Proposed hay grading standards based on laboratory analyses for evaluating quality. J. Anim. Sci. 47, 747-759
SPSS, 2013. IBM SPSS Statistics for Windows. Version 22.0. Armonk, NY: IBM Corp.

Şengül A.Y., Aydın R., 2019. Use of farmatan as an additive to make alfalfa silage. Turk. J. Agr. Nat. Sci. 6, 579-587, https://doi. org/10.30910/turkjans.595395

Tournas V., Stack M.E., Mislivec P.B., Koch H.A., Bandler R., 1998. Yeasts, Molds and Mycotoxins. CFSAN FDA Bacteriological Analytical Manual (BAM). Karen Jinneman (Chair). $8^{\text {th }}$ Edition, Revision A, Chapter 18 